Глава 3. Селекция и семеноводство

\title{
SPECIFICS OF THE INHERITANCE OF DECORATIVE FEATURES IN PELARGONIUM GRANDIFLORUM
}

\author{
Gutiyeva N. M. \\ Federal Research Centre \\ the Subtropical Scientific Centre of the Russian Academy of Sciences, \\ Sochi,Russia,e-mail: ganaza777@yandex.ru
}

The collection of Pelargonium (L'Hérit. ex Ait.) genus that belongs to the family Geraniaceae Juss is cultivated in the Botanical garden «the Tree of Friendship». It has about 200 cultivars. Pelargonium grandiflorum hort hybrids make up $40 \%$ of the total composition. Breeding studies with pelargoniums have been conducted in the FRC SSC of RAS since 2000. They are aimed at creating adaptive, highly decorative, productive and long-blooming cultivars with different flowering periods for universal use. The object of research was a hybrid fund of 24 crossing combinations. The work methods were used for intervarietal hybridization. Inheritance of the main flower decorative features within cultivars and cultivars groups was determined. It was found that seedlings of the studied combinations (60\%) inherited the maternal type of the colour. In most combinations, hybrid seedlings were new growths based on their main colour. The colour of the spot in the main offspring from different crossing combinations was $50-100 \%$ different from the original forms. From $70 \%$ to $100 \%$ of hybrid seedlings of the female parent 'Jolenta' inherited its type and main colour. 'African Belle' cultivar, regardless of whether it is a pollinator or a mother form, transmits its type and colour of the spot to most of the offspring.

Key words: large-flower pelargonium, breeding, hybridization, parent forms, seedlings, inheritance of features.

УДК 635.924

doi: 10.31360/2225-3068-2020-75-55-59

\section{ОТБОР ДЕКОРАТИВНЫХ ФОРМ ЛЕЩИНЫ ОБЫКНОВЕННОЙ НА СЕВЕРО-ЗАПАДНОМ КАВКАЗЕ}

Исущева Т. А., Пчихачев Э. К.

\author{
Адыгейский филиал \\ Федерального государственного бюджетного учреждения науки \\ «Федеральный исследовательский центтр \\ «Субтропический научный центр Российской академии наук», \\ nос. Цветочный, Адыгея, Россия, e-mail: tanyaisusheva@mail.ru
}

В данной статье даны результаты научной работы, проводимой в Адыгейском филиале ФИЦ СНЦ РАН в направлении отбора орехоплодных культур по признаку декоративности. Объектом исследования является лещина обыкновенная. В результате проведённых экспедиционных обследований выделены две формы лещины обыкновенной с декоративными побегами и с 
декоративными листьями для дальнейшего детального изучения. Отобранные формы являются одновременно декоративными, а также имеют хорошее качество плодов и вполне пригодны для употребления в пищу. В статье даны фотографии декоративных форм, приведена информация о месте произрастания, а также методическое описание ботанических признаков.

Ключевые слова: лещина обыкновенная, декоративные формы, выделение, изучение, декоративные признаки, побеги, листья, качество плодов.

В современном мире существует большой спрос на декоративные плодовые, в том числе, орехоплодные растения, в частности, на лещину [6]. В настоящее время в Республике Адыгея не изучен полиморфизм лещины обыкновенной по декоративным признакам [11]. Поэтому необходимо изучить местную популяцию лещины обыкновенной, что является важным для садоводов-любителей, а также для ландшафтной архитектуры $[7,9]$. Это позволит избежать ненужных затрат на интродуцирование декоративных форм и существенно сократит селекционный процесс [1].

Объекты и методы. С 2016 г. в Адыгейском филиале ведутся работы по выделению, отбору и изучению декоративных форм лещины обыкновенной. Эти работы проводятся в рамках темы «Изучение полиморфизма и статистических характеристик плодов лещины для разработки научных основ оптимизации селекционного процесса».

Лещина в районе изучения произрастает на высотах от 200 до 1500 м над уровнем моря. С 2016 г. проводятся экспедиционные обследования лесных участков с естественно произрастающей лещиной. Были выделены две декоративные формы в среднегорной части Адыгеи на Азишском хребте на высоте 1400 метров над уровнем моря. Место произрастания поляна. Методическое описание ботанических признаков декоративных форм даётся по «Классификатору рода Corylus (Tourn.) L. (лещина)» [10].

Результаты и их обсуждение. По совокупности декоративных признаков при обследовании лесных участков для дальнейшего изучения была выявлена декоративная форма лещины № 1. Выделенная форма отличается декоративной изогнутостью побегов [4] и декоративностью листовой пластины, имеющей ольховидную форму $[2,3,5]$. Данная форма лещины высажена на коллекционном участке Адыгейского филиала для дальнейшего изучения на подтверждение декоративности признаков (рис. 1).

Это низкорослый куст, с кроной округлой формы, высотой 1 м, диаметром $0,80 \times 0,50$ м. Облиственность и густота кроны редкая. В кусте 4 основных побега светло-серого цвета. Направление роста побега вертикальное, угол отхождения обрастающих ветвей побега острый, побеги изогнутые. Форма листовой пластинки широкоовальная. Степень рассечённости листа слабая. Форма верхушки листа коротко заострённая. 
Глава 3. Селекция и семеноводство

Форма основания листа мелко-сердцевидная. Тип зазубренности края листа - двоякопильчатый. Размер зазубренности листа мелкий. Опушённость верхней поверхности листа отсутствует, окраска с солнечной стороны листа - зелёная.

По совокупности декоративных признаков при обследовании лесных участков для дальнейшего изучения была выявлена декоративная форма лещины № 2. Данная форма отличается декоративным цветом кроны и декоративной формой листовой пластины $[2,3,5]$. Выявленная форма будет исследоваться на коллекционном участке Адыгейского филиала для подтверждения декоративности признаков (рис. 2).

Это низкорослый куст, удлинённо-овальной формы, высотой 2 м, диаметром 1,5 × 1,5 метра. Облиственность и густота кроны средняя. В кусте 11 побегов светло-серого цвета. Направление роста побега вертикальное, угол отхождения обрастающих ветвей побега острый, побеги - прямые. Форма листовой пластинки широкоовальная. Степень рассечённости листа слабая. Форма верхушки листа коротко заострённая. Форма основания листа мелкосердцевидная. Тип зазубренности края листа - двоякопильчатый. Размер зазубренности листа мелкий. Опушённость верхней поверхности листа отсутствует, окраска с солнечной стороны листа - светло-зелёная.

Отбираемые формы лещины обыкновенной являются одновременно декоративными, а также имеют хорошее качество плодов и вполне пригодны для употребления в пищу [8].

В результате проведённых экспедиционных обследований выделены две формы лещины обыкновенной с декоративными побегами и с декоративными листьями. Кроме декоративных свойств, выделенные формы также имеют хорошее качество плодов для пищевых целей.
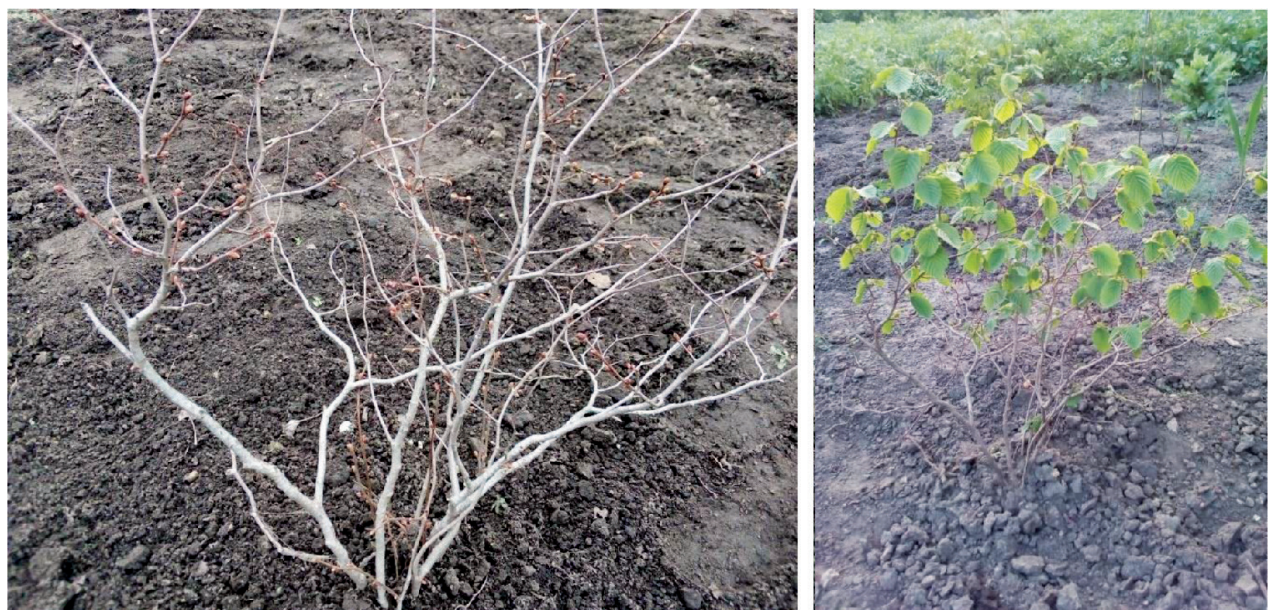

Рис. 1. Форма № 1 с декоративными побегами 

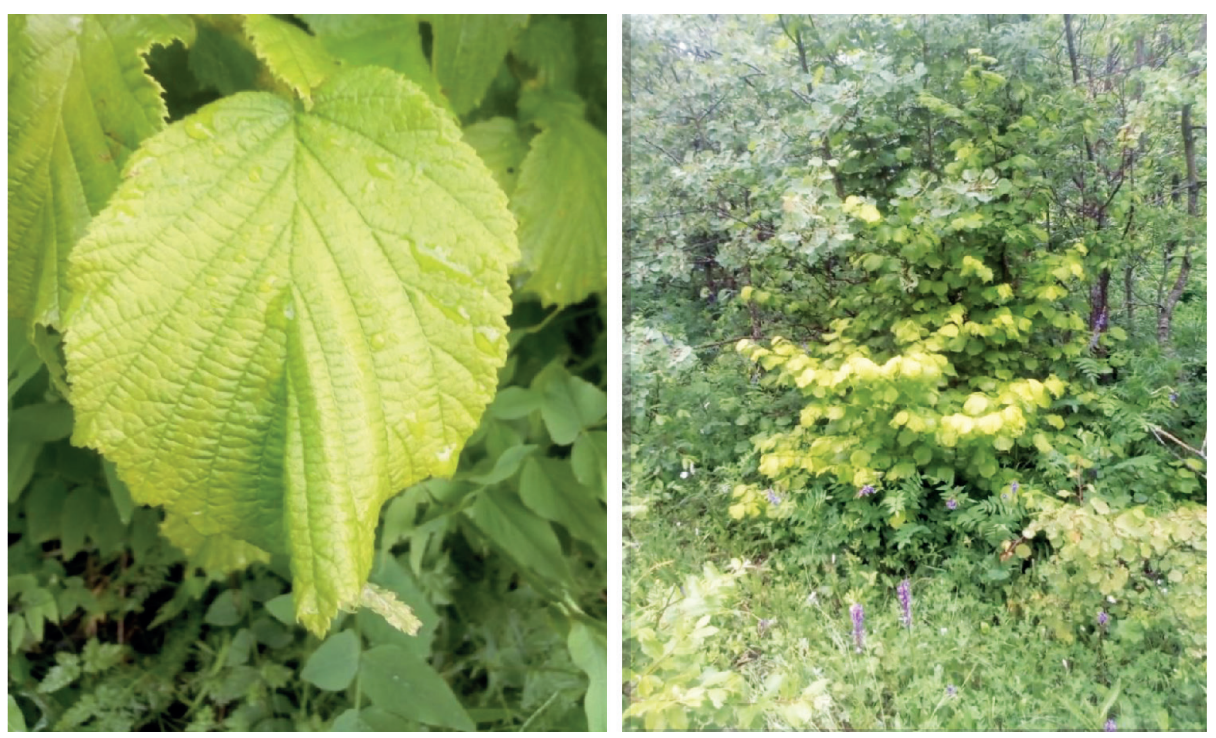

Рис. 2. Форма № 2 с декоративными листьями

\section{Библиографический список}

1. Биганова С.Г., Сухоруких Ю.И., Биганова Е.О. Возможный генетический прогресс при отборе лещины обыкновенной в естественной популяции на Северо-Западном Кавказе // «Наука и образование в жизни современного общества»: сборник научных трудов Международной научно-практической конференции, 29 ноября 2013 г. - Тамбов: ООО "Консалтинговая компания Юком", 2013. - С. 14-16. - ISBN 978-5-4343-0453-5.

2. Биганова С.Г., Сухоруких Ю.И., Исущева Т.А. Изменчивость показателей качества плодов лещины обыкновенной в зависимости от условий произрастания // Новые технологии. - 2013. - № 1. - С. 59-65. - ISSN 2072-0920.

3. Биганова С.Г., Сухоруких Ю.И., Исущева Т.А. Изучение морфологической изменчивости некоторых признаков листьев лещины обыкновенной для целей декоративного садоводства // Субтропическое и декоративное садоводство. - 2019. - № 68. - С. 27-31. - doi: 10.31360/2225-3068-2019-68-27-31.

4. Биганова С.Г., Сухоруких Ю.И., Исущева Т.А. Полиморфизм побегов лещины в природной популяции на северо-западном Кавказе // Субтропическое и декоративное садоводство. - 2020. - № 72. - С. 79-85. - doi: 10.31360/2225-3068-2020-72-79-85.

5. Биганова С.Г., Сухоруких Ю.И., Пчихачев Э.К., Исущева Т.А. Морфологическое разнообразие листьев и прогноз встречаемости аналогичных форм в естественных насаждениях лещины // Новые технологии. - 2019. - № 1. - С. 278-288. - ISSN 2072-0920.

6. Встовская Т.Н. Декоративные формы ольхи, березы и лещины, рекомендуемые для первичного испытания в культуре в Сибири // Растительный мир азиатской России: Вестник Центрального Сибирского ботанического сада СО РАН. - 2011. - № 1(7). - С. 78-86. - ISSN 1995-2449.

7. Исущева Т.А. Отбор декоративных форм лещины обыкновенной в Адыгее // Субтропическое и декоративное садоводство. - 2017. - № 62. - С. 147-151. - ISSN 2225-3068. 
8. Исущева Т.А., Биганова С.Г., Пчихачев Э.К., Пальников И.А. Изучение популяции лещины обыкновенной в Республике Адыгея по качеству плодов // Современные проблемы науки и общества, 29 марта-03 апреля 2018 г. Майкоп: матлы Всероссийской научно-практической конференции аспирантов. - Майкоп: МГТУ, Изд-во Кучеренко, 2018. - С. 82-87. - ISBN 9875907004146.

9. Исущева Т.А., Пчихачев Э.К., Пальников И.А. Предварительный отбор декоративных форм лещины обыкновенной в Республике Адыгея // Субтропическое и декоративное садоводство. - 2018. - № 65. - С. 100-104. ISSN 2225-3068.

10. Коваль Г.К., Денисов В.П. Классификатор рода Corylus (Tourn.) L. (Лещина). - Л.: Изд-во ВНИИР им. Вавилова, 1981. - 26 с.

11. Сухоруких Ю.И., Биганова С.Г. Полиморфизм качественных признаков лещины обыкновенной на Северо-Западном Кавказе // Новые технологии. - 2013. - № 3. - С. 115-123. - ISSN 2072-0920.

\title{
SELECTING ORNAMENTAL FORMS OF COMMON HAZEL IN THE NORTHWEST CAUCASUS
}

\section{Isushcheva T. A., Pchikhachev E. K.}

\author{
Adygei Branch \\ of the Federal Research Centre the Subtropical Scientific Centre \\ of the Russian Academy of Sciences, \\ v.Tsvetochnyy, the Republic of Adygea, Russia, e-mail: tanyaisusheva@mail.ru
}

This paper presents the results of scientific work carried out in the Adygei Branch of FRC SSC of RAS which aimed to select nut crops on the basis of decorativeness. The object of research is common hazel. As a result of the expedition surveys, two forms of common hazel with decorative shoots and with decorative leaves were identified for further detailed study. Besides being decorative, the selected forms also have good fruit quality and are quite suitable for eating. The paper contains photos of decorative forms, information about the place of growth, as well as a methodical description of botanical features.

Key words: common hazel, decorative forms, selection, study, decorative features, shoots, leaves, fruit quality. 